\title{
Challenges of Anticoagulant Rodenticides: Resistance and Ecotoxicology
}

\author{
Philippe Berny \\ Toxicology laboratory, UMR INRA 1233, VetAgro Sup,
}

France

\section{Introduction}

Control of rodent pests worldwide relies heavily on the use of rodenticides. In the 40s', O'Connor (1948) isolated and first suggested the use of dicoumarol (a naturally occurring substance responsible for the "sweet clover disease" in cattle) as a rodenticide. In the early $50 \mathrm{~s}^{\prime}$, anticoagulant rodenticides (warfarin and later indane-dione derivatives) replaced the acute poisons with great success. It is well known that Norway rats (Rattus norvegicus) are very suspicious to new, unfamiliar items in their environment (neophobia) and may eat only a small, non-lethal dose of a new bait. If they survive, they learn to avoid the bait. This phenomenon is also known as food aversion (Lund, 1972). Neophobia may also extend to bait boxes and traps when first introduced in the rat environment. Unlike rats, house mice do not exhibit neophobia (Bonnefoy et al, 2008). As Anticoagulant (or anti-vitamine K AVK) compounds are cumulative, small amounts ingested daily will eventually lead to the consumption of a lethal dose. In the early $60 \mathrm{~s}^{\prime}$, massive use of these first generation AVK was considered a great opportunity to reduce or even eradicate rat populations from many areas at that time, despite their behavioral traits. First-generation AVK include warfarin, coumafuryl, coumachlor, coumatetralyl, diphacinone, pindone and chlorophacinone (Bentley, 1972).

Unfortunately, a first detection of a resistant strain of rats was reported in Scotland in 1958, followed by similar reports in other areas in Europe: Wales, Denmark, the Netherlands, and Germany (Lund, 1972). At the same time, Brooks and Bowerman (1973) tested several strains of Norway rats from New York City and confirmed that warfarin resistance was also common among rat populations heavily treated with warfarin in the US. The World Health Organization (WHO) rapidly recognized this event and suggested some guidelines for the rapid detection of resistant rodent, based on feeding tests (Drummond and Rennison, 1973). Pelz et al. (2005) published a survey of countries reporting resistance in commensal rodents (2005). The major findings are described in Table 1 below.

Recently, warfarin resistance has also been reported in another rat species: the Lesser Ricefield rat (Rattus losea) (Wang et al., 2008).

Rodent species can develop complex behavioral patterns and one of this is considered to be "behavioral resistance". There is evidence, for instance in the roof rat, that animals can learn to avoid toxic baits (Leung and Clark, 2005). This complex approach has not been given full attention and will not be developed in this review. 


\begin{tabular}{|c|c|c|c|c|}
\hline Country & $\begin{array}{l}\text { Rattus } \\
\text { norvegicus }\end{array}$ & $\begin{array}{l}\text { Rattus } \\
\text { rattus }\end{array}$ & $\begin{array}{c}\text { Mus } \\
\text { musculus }\end{array}$ & Reference \\
\hline Belgium & + & $?$ & + & Lund 1984; Baert, 2003 \\
\hline Danemark & + & + & + & $\begin{array}{l}\text { Myllymaki, 1995, } \\
\text { Lodal, } 2001\end{array}$ \\
\hline Finland & $?$ & $?$ & + & Myllymaki, 1995 \\
\hline France & + & + & + & $\begin{array}{l}\text { Myllymaki, 1995, Pelz } \\
\text { et al., 2005, Lasseur et } \\
\text { al., } 2005\end{array}$ \\
\hline Germany & + & + & + & $\begin{array}{l}\text { Myllymaki, 1995, Pelz, } \\
\text { 2001, Pelz et al., } 2005\end{array}$ \\
\hline Italy & + & $?$ & $?$ & $\begin{array}{l}\text { Alessandroni et al., } \\
1980\end{array}$ \\
\hline Sweden & $?$ & $?$ & + & Lund, 1984 \\
\hline Switzerland & $?$ & $?$ & + & Muhr, 1981 \\
\hline United Kingdom & + & + & + & $\begin{array}{l}\text { Myllymaki, 1995, } \\
\text { Kerins et al., } 2001\end{array}$ \\
\hline Argentina & $?$ & $?$ & + & Guidobono et al., 2009 \\
\hline Canada & + & $?$ & + & $\begin{array}{l}\text { Siddiqi and Blaine, } \\
1982\end{array}$ \\
\hline USA & + & + & + & $\begin{array}{l}\text { Jackson and Ashton, } \\
1981\end{array}$ \\
\hline Australia & $?$ & + & $?$ & Saunders, 1978 \\
\hline New-Zealand & + & $?$ & + & De Jonge, 1994 \\
\hline Japan & $?$ & + & $?$ & Naganuma et al, 1981 \\
\hline Korea & + & $?$ & $?$ & Rost et al., 2009 \\
\hline
\end{tabular}

Table 1. Warfarin resistance in the Norway rat (Rattus norvegicus), the roof rat (Rattus rattus) and the house mouse (Mus musculus) around the world (completed from Pelz et al., 2005) 
As a consequence and in order to overcome this resistance phenomenon, other AVK were developed. These compounds are active after a single feeding, which makes them even more effective against neophobic rodents. They are usually more toxic and more persistent in animal tissues. These second-generation AVK include bromadiolone, difenacoum, brodifacoum and flocoumafen (Redfern and Gill, 1980 ; Petterino and Paolo, 2001).

Table 2 reports the name, rat LD50s for AVKs currently used in most countries around the world.

All the anticoagulants developed so far are based on three moieties:

- $\quad$ the coumarin derivatives (7)

- $\quad$ the indanedione derivatives (3)

- $\quad$ the benzothiopyranone derivatives (1)

The structures of all these compounds are described in Figure 1 below.

\begin{tabular}{|lcc|}
\hline Compound & Rat Oral LD50 $(\mathrm{mg} / \mathrm{kg})$ & Source \\
\hline Warfarin & $1.6-50$ & Toxnet \\
Coumachlor & 187 & Toxnet \\
Coumatetralyl & 30 & Toxnet \\
Chlorophacinone & $2.1-50$ & Toxnet \\
Diphacinone & 1.5 & Toxnet \\
Pindone & 280 & Toxnet \\
Bromadiolone & 0.49 & Toxnet \\
Brodifacoum & 0.16 & Toxnet \\
Difenacoum & 0.68 & Toxnet \\
Flocoumafen & 0.25 & Toxnet \\
Difethialone & 0.55 & Toxnet \\
\hline
\end{tabular}

Table 2. Rat oral LD50 of anticoagulant rodenticides 
<smiles>CC(=O)CC(c1ccccc1)c1c(C)c2ccccc2oc1=O</smiles>

Warfarin<smiles>CC(=O)CC(c1ccc(Cl)cc1)c1c(N)c2ccccc2oc1=O</smiles>

Coumachlore<smiles>O=c1oc2ccccc2c(O)c1C1CCCc2ccccc21</smiles>

Coumateratyl<smiles>CCCCCCCCCC(=O)c1c(C(CC(S)c2ccc(-c3ccc(Br)cc3)cc2)c2ccccc2)c(=O)oc2ccccc12</smiles><smiles>O=c1oc2ccccc2c(Cl)c1C1CC(c2ccc(-c3ccccc3)cc2)Cc2ccccc21</smiles>

Difenacoum<smiles>O=c1oc2ccccc2c(O)c1C1CC(c2ccc(-c3ccc(Br)cc3)cc2)Cc2ccccc21</smiles><smiles>O=c1oc2ccccc2c(Br)c1C1CC(c2ccc(OCc3ccc(C(F)(F)F)cc3)cc2)Cc2ccccc21</smiles><smiles>O=C1c2ccccc2C(=O)C1C(=O)C(c1ccccc1)c1ccccc1</smiles>
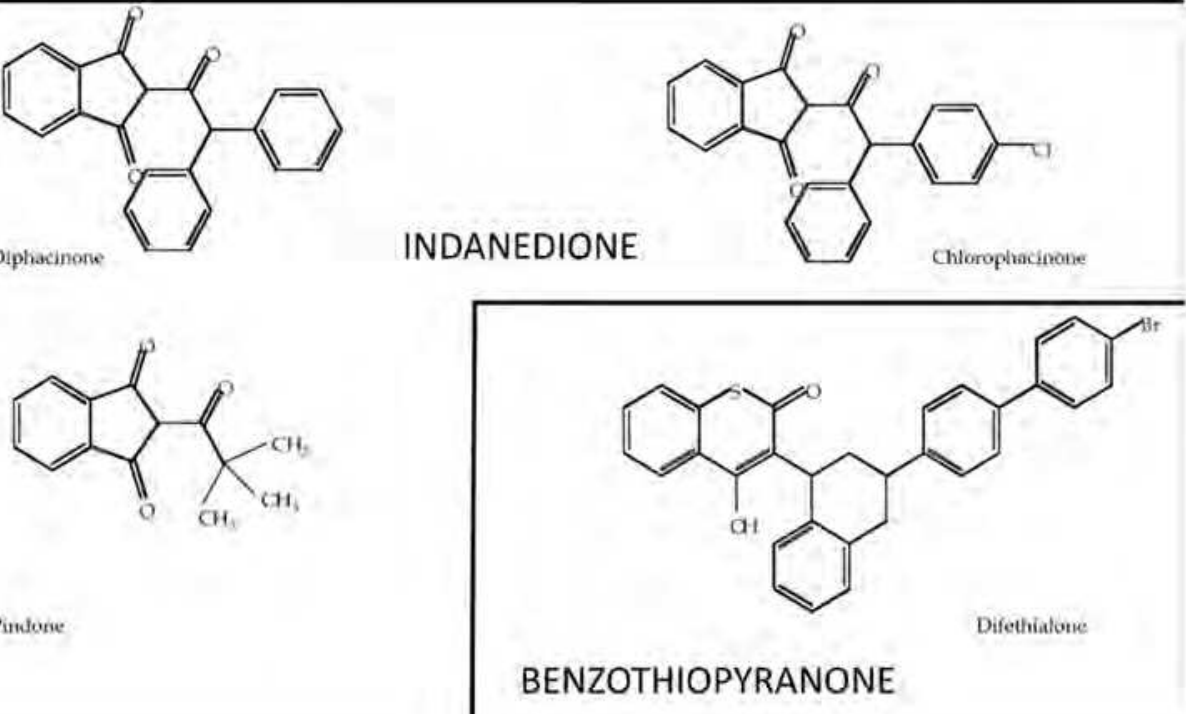

Pindore

Fig. 1. Chemical structure of anticoagulant rodenticides grouped by moiety 
These anticoagulant rodenticides share their mode of action: they all are anti-vitamine $\mathrm{K}$ compounds and their effects on mammals and birds are very similar. The general overview of this mechanism of action is described in figure 2 .

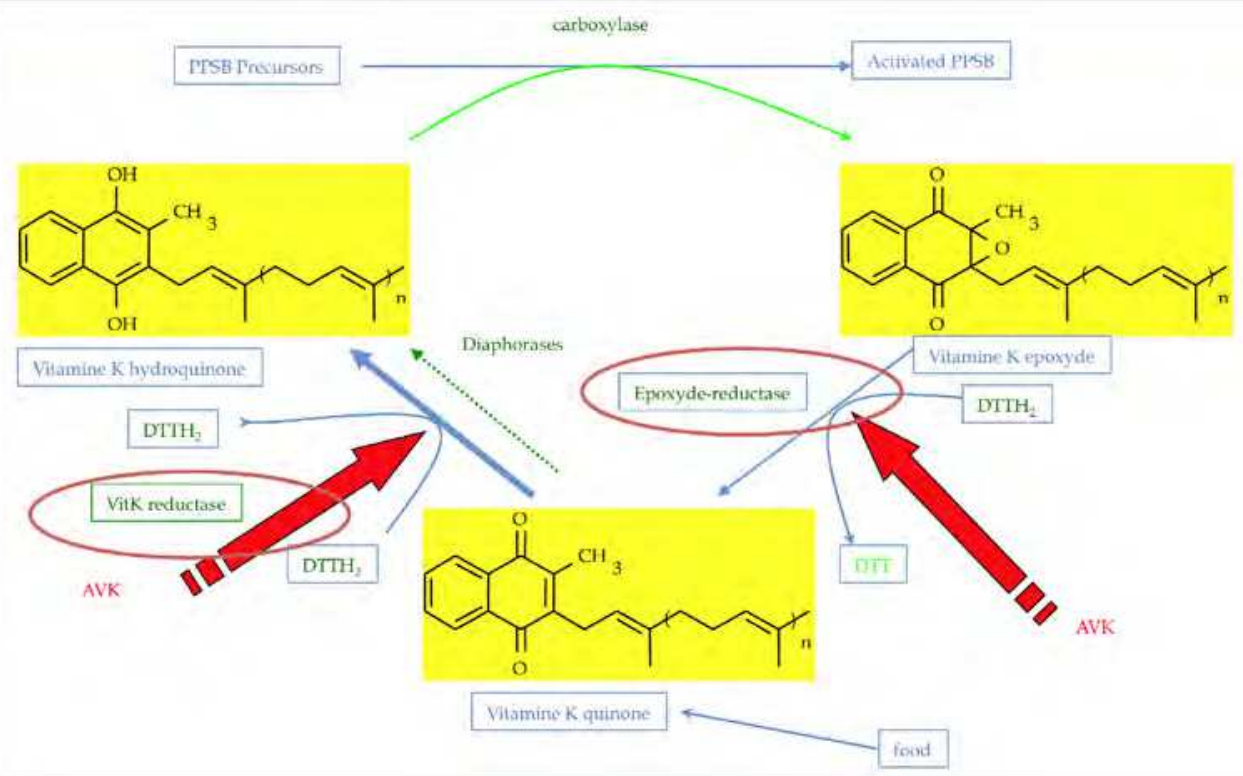

Fig. 2. Mechanism of action of anticoagulant rodenticides on the Vitamin K cycle

AVKs can inhibit two different enzymes of the vitamine K cycle: the epoxyde reductase and the vitamine $\mathrm{K}$ reductase (although some scientists consider these two enzymes are, in fact a single protein as suggested by Fasco et al., 1982) (Petterino and Paolo, 2001). Clearly, as indicated by the arrow size, the epoxyde reductase is the rate-limiting step and inhibition by AVK will result in the accumulation of Vitamine K epoxide, which is not active. The second step is not as critical, since other pathways may lead to the activation of vitamine $K$, such as the diaphorases. Inhibition of this vitamin $\mathrm{K}$ cycle results in a decreased production of active coagulation factors which, in turn, will result in coagulation disorders and hemorrhages after $48 / 72 \mathrm{~h}$.

\section{The genetic basis of resistance}

\subsection{Background}

Evidence of resistance to AVK was clearly reported at the end of the 50s' (Boyle, 1960) and observed in several European countries shortly thereafter as reported by Lund (1972). For years, the only evidence of resistance was based on feeding tests, as recommended by the WHO (Drummond and Rennison, 1973). Feeding tests performed with warfarin over 4 days are still considered a good indicator of phenotypic resistance and recommended by the WHO in order to evaluate the resistance of a given population in live-trapped animals (WHO, 1982). Basically, rodents are fed a diet made of wheat $+250 \mathrm{mg} / \mathrm{kg}$ warfarin for 4 days and mortality is evaluated until day 21. Phenotypic evaluation of resistance to AVK 
also relied on evaluation of coagulation (WHO, 1982). The biochemical basis of resistance was eventually established in the 1990s' when VKOR enzymatic activity could be assessed in liver microsomes. Misenheimer and Suttie (1990) established the enzymatic characteristics of a Chicago-resistant strain of rats, and showed that VKOR was inhibited by warfarin, but that this inhibition was partially reversible. Later, Misenheimer et al. (1993) showed that, in a Danish resistant strain of mice, VKOR enzymatic constants were altered: reduced Vmax, reduced $\mathrm{Km}$, and also this enzyme was highly insensitive to in vitro inhibition by bromadiolone or warfarin.

It was rapidly established that resistance was an inheritable trait associated to a single autosomal gene Rw (Resistance to warfarin) located on chromosome 1 (Greaves and Ayres, 1969). This gene was later found to be linked with the microsatellite D1Rat219 (Lasseur et al, 2005). The first reports of resistance were mostly concerned with first generation AVKs. It soon became obvious, however, that some strains of rats had also developed resistance to the newer second generation AVK, such as difenacoum, bromadiolone or even brodifacoum. Greaves et al (1982), for instance, report a field trial in a wild population showing evidence of difenacoum resistance in Southern UK. Although bromadiolone and brodifacoum had proven effective in laboratory tests, field trials were surprisingly disappointing with $51 \%$ lethality over 14 days and $83 \%$ after 35 days. As a consequence, in order to overcome this resistance, the authors suggested at that time to increase the rodenticide concentration in baits (up to $500 \mathrm{mg} / \mathrm{kg}$ bromadiolone), since they did not experience any loss of palatability in laboratory tests. Eventually, Greaves (1994) defined resistance as a major lack of efficacy of AVKs used correctly and under normal circumstances. This lack of efficacy is due to the presence of a strain of rodents less susceptible to AVKs, and this reduced susceptibility is genetically transmitted.

In the house mouse, resistance was also rapidly described (Wallace and McSwiney, 1976) and closely linked with the Frizzy (fr) gene on chromosome 7, in a linkage group similar to the one carrying Rw in the rat. Already in these early works on resistance, females appeared more resistant than males. The results also suggested that resistance was a dominant trait influenced by sex.

These historical data and early works on resistance suffered from one major problem: the genetic basis of resistance was not known and could not be further investigated. Some studies are in favor of a metabolic resistance (i.e. increased degradation by cytochrom P450), especially in the roof rat or the house mouse (Sutcliffe et al., 1990, Sugano et al., 2001). Very few data are available on this metabolic hypothesis in the Norway rat. Metabolic resistance will be discussed for each species.

Recent advances in genetics in the Norway rat constituted a real breakthrough.

\subsection{The Norway rat}

Although the biochemical tools to study VKOR have long been available, it was not until recently that biochemical investigation and biochemical characterization of VKOR activity was given full attention in rats. This approach has also been associated with recent genetic advances and the identification of the first gene involved in the synthesis of the VKOR enzyme (often presented as a complex, since many authors considered that VKOR activity was supported by several proteins) (Li et al., 2004, Rost et al., 2004).

This first gene (Vkorc1) is clearly located on the chromosome 1 of the rat, associated with the D1Rat219 microsatellite. Mutated forms are associated with severe changes in VKOR 
activity (Rost et al, 2004). The gene is rather small (1800 bp), with 3 exons and encodes a small trans-membrane protein $(163 \mathrm{AA})$. This small protein $(18 \mathrm{kDa})$ has been computed and a suggested structure has been published (Tie et al, 2005) as depicted in Figure 3. This protein has three trans-membrane domains. It is embedded in the endoplasmic reticulum. The catalytic center is considered to be the redox center C-X-X-C (C132 and C135), essential to the activity of the enzyme (Wajih et al., 2004). Back-crossing of resistant rats carrying the Y139F mutation into Spraque-Dawley susceptible rats over 7 generations was used to demonstrate the implication of this mutation in the phenotypic resistance observed via coagulation tests. Indeed, homozygous resistant rats (with less than 1.5\% genetic material from the original resistant male, around the Vkorc1 gene) developed a phenotypic resistance similar to their wild counterparts. At the same time, it was demonstrated that Vkorc1 resistance is a co-dominant resistance, since heterozygous individuals are less intermediate between resistant and susceptible rodents (Grandemange et al., 2009).

In Europe, several strains of rats, known to be genetically resistant display some mutations at various loci, with some "hotspots". For instance, Pelz et al (2005) analyzed resistant strains of rats from several countries in Europe and described several mutations associated with the phenotypic resistance, as well as the VKOR activity in recombinant cells transfected by VKORC1 as described in Table 3.

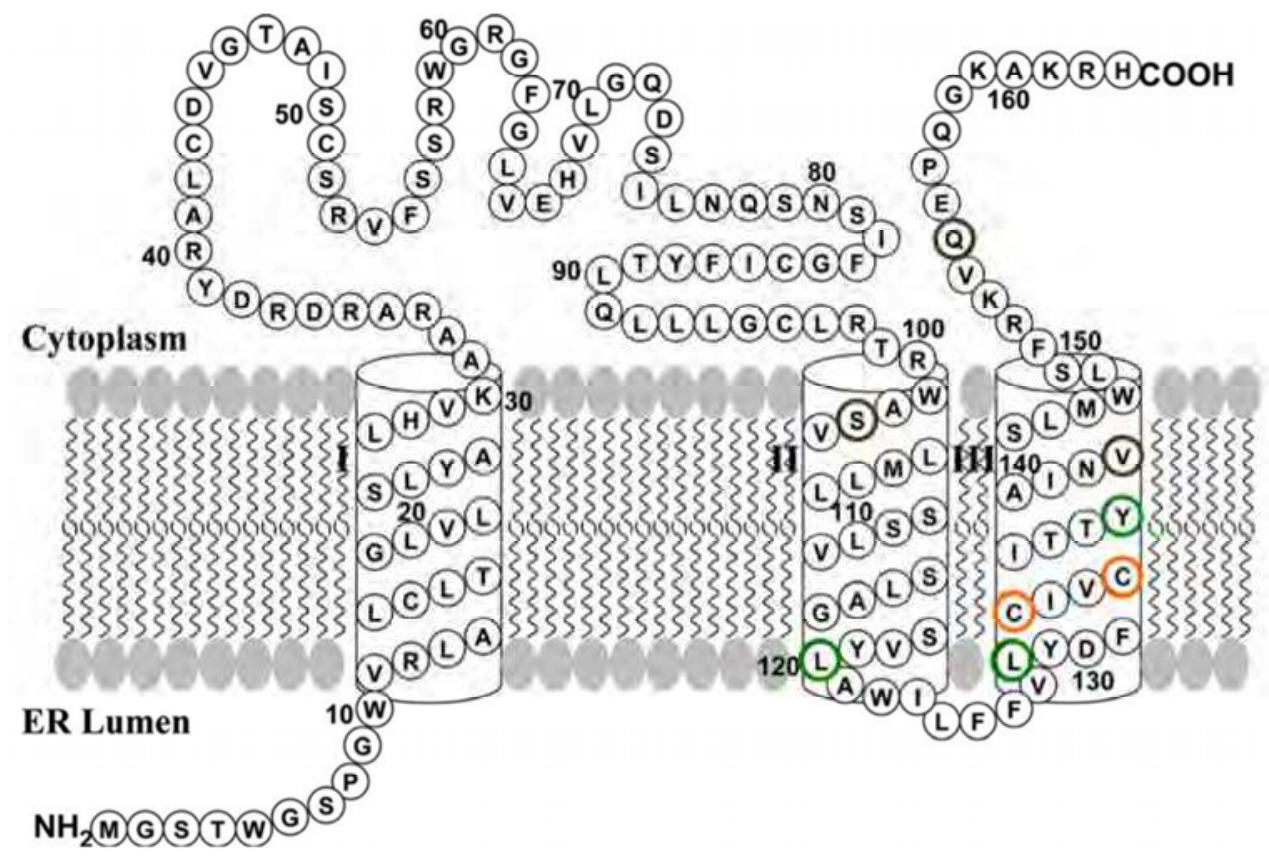

Fig. 3. Theoretical topology of VKORC1 (163 Amino Acids), with some of the known mutation points (green and brown circles: L120, L128, Y139, V142 for instance)-adapted from Tie, JK et al. J. Biol. Chem. 2005; 280: 16410-16416 


\begin{tabular}{|lcc|}
\hline Species / strain & Area & Codon and mutation \\
\hline Rattus norvegicus & UK, Hampshire & L120Q \\
Rattus norvegicus & UK, Berkshire & L120Q \\
Rattus norvegicus & UK, Scotland & L128Q \\
Rattus norvegicus & UK, Wales & Y139S \\
Rattus norvegicus & DK & Y139C \\
Rattus norvegicus & D & Y139C \\
Rattus norvegicus & B & Y139F \\
Rattus norvegicus & F & Y139F \\
Rattus norvegicus & HU & Y139C \\
\hline
\end{tabular}

Table 3. Some common mutations described in the Norway rat in Europe (adapted from Pelz et al., 2005).

Recent studies have identified numerous mutations in Vkorc1 around Europe and especially in France. Indeed, a survey conducted with Pest Control Operators (PCOs') on more than 260 rat samples revealed several interesting data :

- $\quad$ over 92 sampling sites, at least one mutations was identified in 40 sites

- $\quad 37 \%$ of the rat samples were mutated

- homozygous mutated individuals were very common. The geographical distribution of these mutations is described in figure 4.

This figure illustrates the widespread distribution of the Y139F mutation in France (almost $28 \%$ of all samples). Some mutations (E155K, L128S, S103Y) had never been described before. Haplotypes C and D are silent mutations observed on amino acids 107, 137 and 143 and on amino acids 97, 137 and 143 respectively (Grandemange et al., 2010). In their work, Pelz et al (2005) showed that recombinant cells including the Y139 mutations still displayed a high VKOR activity in the presence of warfarin, as compared with other mutations or the wild type. Investigation of the catalytic activity of the mutated enzyme was carried on by Lasseur et al. (2007) and showed that the mutated enzyme is very poorly susceptible to first generation AVKs ' as reported in Table 4 below.

Apart from these two studies, the actual impact of the various mutations detected has not been elucidated and our group is currently working on recombinant cell system dot express these mutants and evaluate the catalytic consequences of the various mutations identified so far, both on the basic activity level of Vkor, but also in response to AVK exposure, since this information can be of critical importance when deciding which rodenticide to use in the field. 


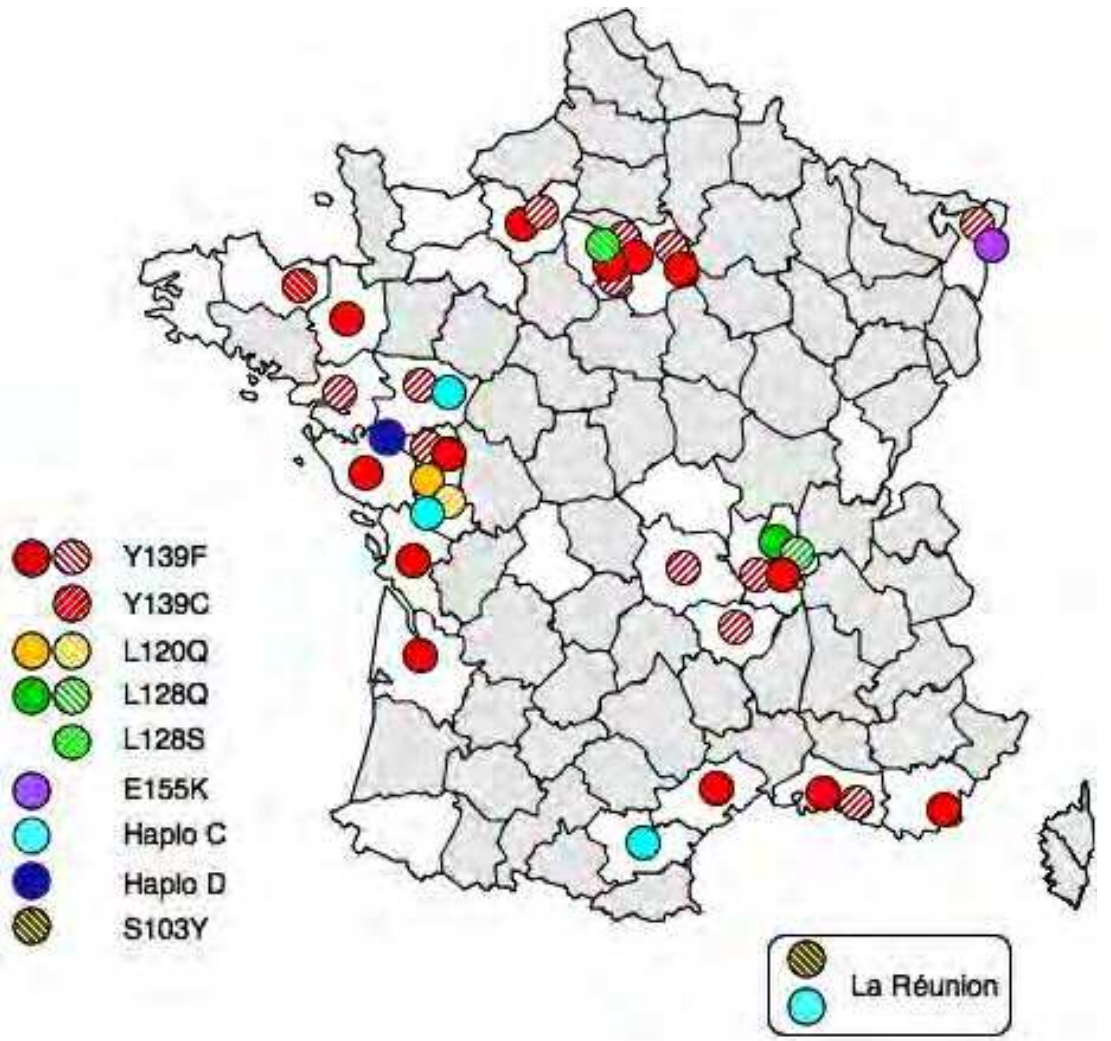

Fig. 4. Sampling area and mutations detected in Norway rats caught in France (full circle: presence of homozygous individuals, dashed circles: only heterozygous individuals) (adapted from Grandemange et al. 2010)

\begin{tabular}{|lcc|}
\hline \multirow{2}{*}{ AVK } & $\begin{array}{c}\text { Ki susceptible microsomes } \\
(\mu \mathrm{M})\end{array}$ & Ki resistant microsomes $(\mu \mathrm{M})$ \\
\hline Warfarin & 0.72 & 29.0 \\
Coumachlor & 0.12 & 1.9 \\
Coumatetraly & 0.13 & 2.7 \\
Diphacinone & 0.07 & 5.0 \\
Chlorophacinone & 0.08 & 1.6 \\
Bromadiolone & 0.13 & 0.91 \\
Difenacoum & 0.07 & 0.26 \\
Brodifacoum & 0.04 & 0.09 \\
\hline
\end{tabular}

Table 4. Inhibition constant $(\mathrm{Ki}, \mu \mathrm{M})$ for wild-type or resistant rat microsomes. adapted from Lasseur et al., 2007 
There is some evidence, at least in the Chicago-resistant strain, that some other proteins may play a role in the resistance phenomenon. Indeed, in this strain, Vkorc1 is not modified but a chaperone protein (calumenine) is over-expressed in resistant rats and not expressed in susceptible rats (Wajih et al., 2004). This pathway has not been described anywhere and, for instance, in the French strain carrying the Y139 mutation, calumenin is not overexpressed (Lasseur et al., 2005).

The metabolic hypothesis has been suggested for several years. Several isoforms of Cytochrom P450 (CYP450) are involved in the biotransformation of warfarin. Hydroxylation of warfarin by CYP450 is mainly due to CYP2C, CYP2B, CYP1A and CYP3A subfamilies. Several hydroxides are identified in the rat: 4'-, 6-, 7-, 8-, and 10-OH warfarin. These metabolites are more water soluble and may also undergo glucuronidation and urinary excretion (Ishizuka et al., 2006). There is however, to date, limited evidence of any metabolic resistance in the Norway rat published. Markussen et al. (2007) reported higher constitutive expression of various CYP isoforms in a resistant strain from Denmark. The over-expressed CYP were CYP2C13, CYP3A2. Upon bromadiolone exposure, several isoforms were induced: CYP1A2, CYP2C13, CYP2E1, CYP3A2 and CYP3A3. It is noteworthy that some of these isoforms are involved in the metabolism of warfarin. There is no evidence, however, that this overexpression or induction results in increased metabolism and reduced half-life of bromadiolone, which would be expected as a resistance phenomenon. Similarly, Heiberg (2009) confirmed the presence of phenotypic resistance to bromadiolone in wild rats from Denmark, without any mutation detected in the Vkorc1 gene.

One of the hypothesized consequences of Vkorc1 mutations is a potential vitamin $\mathrm{K}$ deficiency. Some work has been conducted on that matter and there is conflicting evidence on vitamin K requirements of resistant rats. For instance, Hermodson et al (1969), Greaves and Ayres (1973) clearly showed that the Welsh resistant strain was highly dependent on high daily vitamine $\mathrm{K}$ (about 13 times the standard requirements) in order to maintain normal coagulation. More recently Markussen et al. (2003) showed, on a Danish resistant strain, that the animals were moderately but significantly deprived of vitamin $\mathrm{K}$ and had higher daily requirements than susceptible individuals. Comparatively, based on enzymatic evaluation, the French resistant strain described by Lasseur et al., does not present any vitamin $\mathrm{K}$ deficiency $(\mathrm{Km} / \mathrm{Vm}$ ratio constant) (Lasseur et al., 2005). This vitamin $\mathrm{K}$ deficiency could be a biological cost associated with resistance to AVK. In the Danish strain, Heiberg et al. (2006) showed that homozygous resistant rats had a lower reproductive success than expected and that heterozygous males or females had a better reproductive success. They suggested that the vitamin K deficiency may play a role in this phenomenon, especially in pregnant females, for which vitamine $\mathrm{K}$ is primarily directed to developing fetuses, thereby reducing their vitamin $\mathrm{K}$ status.

As a conclusion, Vkorc1 mutations appear to play a major role in the development of resistance in the Norway rat, with evidence from all over the world that these mutations are common and vary diverse in nature. A lot of work remains to be done in order to evaluate the individual consequences of each of these mutations on the catalytic properties of the enzyme, in order to adapt the AVK use to the resistance level observed in a given area, and some work is still needed to investigate the biological costs potentially associated with vkorc1 resistance.

\subsection{The roof rat}

Comparatively few information is available for the roof rat. There is no evidence of Vkorc1dependent resistance, but the gene has been sequenced and is highly conserved (Ishizuka et 
al., 2006). Species-spcific microsatellitaes have also been identified to help determine Vkorc1 sequence and potentially identify SNPs' in the gene sequence (Diaz et al., 2010). In this study, none of the roof rat tested had any mutation known to confer resistance. Sugano et al (2001) described a resistant strain in Tokyo with evidence of metabolic resistance. . In a wild resistant Rattus rattus population in Tokyo, Ishizuka et al. (2006) failed to detect any mutation in Vkorc1. The authors investigated the potential involvement of CYP isoforms in the metabolism of warfarin. Based on a one-month feeding trial, they selected surviving rodents as resistant. A first evidence of metabolic differences was detected with higher plasma concentrations of warfarin in susceptible rats vs resistant rats. The CYP profile exhibited an increased expression of CYP3A subfamily, known to be involved in the metabolism of warfarin, and especially in the production of $10-\mathrm{OH}$ warfarin, which was clearly more produced in resistant rats (Ishizuka et al., 2006). These hydroxylated metabolites are known to be less or even not active on the coagulation process, thereby confirming the lack of susceptibility of rodents. Ishizuka et al. (2007) also demonstrated that $\mathrm{NADPH}$ cytochrome $\mathrm{c}$ reductase activity (dependent on NADPH cytochrome P450 reductase) wasmarkedly higher in resistant rats, with increased general metabolic activity in all degradation pathways of warfarin in resistant animals. As a confirmation, use of a P450 inhibitor (SKF-525A) resulted in a higher mortality rate in animals exposed to warfarin. These results tend to show that CYP-dependent metabolism of warfarin is a resistance pathway for the roof rat (Ishizuka et al., 2008). Unfortunately, there is no other evidence or work related to resistance in the roof rat and it is difficult to compare the resistance level achieved with metabolic resistance as compared with genetic resistance conferred by vkorc1 mutations. Obviously, much still needs to be done on the roof rat, one of the most abundant rat species around the world.

\subsection{The House mouse}

Few studies have considered the House mouse and its resistance status towards AVKs. Indeed, at least from a European perspective, there are still other rodenticides marketed to control mice populations, as for instance alpha-chloralose. Nevertheless, resistance has been rapidly identified in mice after AVKs were introduced on the market in the 50s'. For instance, Redfern and Gill (1980) described warfarin resistance in mice from the UK and the effective use of bromadiolone to overcome this resistance and Lund (1984) also reported resistance in mice. A recent investigation in farm mice in Argentina concluded, however, that resistance was present in South America as well as in other areas of the world (Guidobono et al., 2009). Countries reporting house mouse resistant to AVKs are listed in Table 1.

Despite the limited number of studies available, the results show that the two major resistance pathways exist in the house mouse. Indeed, genetic alterations of vkorc1 have been described and altered VKOR activity or lack of susceptibility to AVKs has been reported (Lasseur et al, 2006) together with a mutation in vkorc1 (W59G). Rost et al. (2009) also described and identified several strains of resistant mice with mutated vkorc1 (R12W, R58G, R61L for instance) and these amino acid substitutions resulted in reduced VKOR activity (33, 39 and 49\% respectively). They also reported a R58G with no evidence of VKOR activity modification and the more common Y139C mutation, known to confer resistance in rats, in mice from Germany and the Azores. VKOR resistance has been known in mice for at least 15 years and some strains have been described as resistant to both warfarin and bromadiolone (Misenheimer et al., 1993). 
In the paper by Lasseur et al. (2006) the catalytic properties of VKOR in the house mouse have been investigated and the results are quite surprising (Figure 5). These data complete the first work by Misenheimer et al. (1993), who only described reduced Km and Vm in resistant Danish mice.
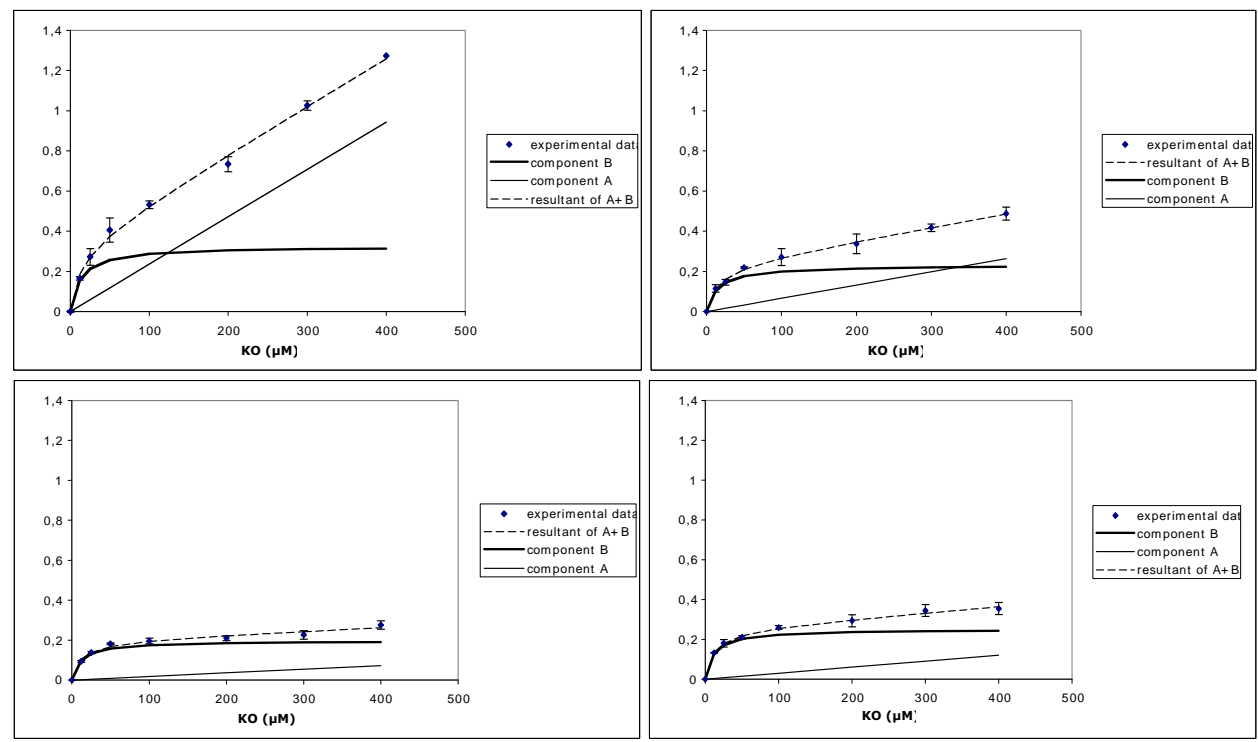

Fig. 5. VKOR activity in the susceptible (left) and resistant (right) mouse without (upper) or with (lower) $1 \mu \mathrm{M}$ warfarin (adapted from Lasseur et al., 2006)

The interpretation of the enzyme activity could only be possible with a bi-component model in which component $\mathrm{A}$ is highly active in the susceptible mouse and highly susceptible to AVK, while the resistant mouse seems to lack this susceptible component A. This complex model advocates for more biochemical studies of the VKOR complex in the House mouse.

Investigation of the metabolic pathways of AVKs also showed evidence of increased metabolic degradation of AVKs. Indeed, Sutclife et al. (1990) treated mice with various P450 inducers and showed that the metabolic profile for Warfarin $4^{\prime}-, 6-, 7-$, and 8-OH metabolites were different between susceptible and resistant strains. Based on this very different metabolic profile and CYP induction pattern, they concluded that CYP450 was highly involved in the resistance of the house mouse to AVKs. The metabolic resistance has not been fully evaluated, though and is only reported for warfarin metabolism. There is still much work to be done in order to evaluate the potential for CYP450 to metabolize other AVKs, especially second generation products such as bromadiolone or difenacoum for instance.

\subsection{Other rodent species}

Apart from the three feral species, very limited information is available on wild rodent resistance status. A Chinese study described resistance in Lesser Rice-field rat (Rattus losea) 
(Wang 2008). This resistance concerns warfarin and has been determined by means of the traditional feeding test.

We have recently published some enzymatic evidence of resistance to warfarin in water voles (Arvicola terrestris) trapped in areas where bromadiolone is repeatedly used to control vole populations, at least several times per year (Vein et al., in press). This resistance does not appear to be linked to a modification of the vkorc1 gene but rather to alterations of the VKOR enzyme function as could be determined by promoter alteration for instance.

\subsection{Evaluating and managing resistance in rodents}

Since resistance is a well-established problem in commensal rodent species, testing for its existence is a necessary preliminary step in order to adapt the AVK control treatment. As of today, there are few relevant techniques : in vivo assays (feeding test, Blood Clotting Resistance test) and in vitro assays (VKOR activity, CYP450 metabolism and vkorc1 testing) (Grandemange et al., 2010).

\subsubsection{Feeding test}

This strategy has been the first developed by the WHO (Drummond and Rennison, 1973). After several revisions, it has been established in its present form in 1982 (WHO, 1982), with various doses of the AVK to test. It is basically a no-choice feeding test over 6 days with a 50 ppm warfarin, bromadiolone or difenacoum bait for instance. Rodents surviving the 5-day test period (+14 days observation) are classified as resistant to the AVK tested. This test needs to be conducted on a sufficient number of animals in order to be significant. It also involves intense trapping and maintaining rat colonies in order to evaluate the resistance status. Some authors consider that this test has several limitations, especially with regards to local variations in the resistance of the strain, which would need adaptation of the exposure period to cover a wider range of susceptibility. Unfortunately, this approach requires a large number of animals and is ethically critical (Gill and McNicoll, 1991).

\subsubsection{BCR testing}

The Blood Clotting Response test (BCR) was first developed by the EPPO (European Plant Protection Organization) (Martin et al., 1979). In its present form, the BCR can be conducted in two ways:

- the first approach is to determine the rat capacity to use the vitamin K epoxide substrate $(1 \mathrm{mg} / \mathrm{kg})$ as a vitamin $\mathrm{K}$ source in the presence of an AVK such as warfarin $(5 \mathrm{mg} / \mathrm{kg})$. Determination of the clotting response (Prothrombin time) 24hours later is a good indicator of the resistance status. A revised version of this test only relies on the administration of a low dose $(1 \mathrm{mg} / \mathrm{kg})$ warfarin, with no vitamine $\mathrm{K}$ epoxyde and investigation of the clotting capacity 24 hours later. The recent developments of this approach are based on the works by Gill and McNicoll (1993) and Prescott and Buckle (2000), who tested several protocols with various AVKs. These works led to the production of a technical Monograph by the Rodenticide Resistance Action Committee (http://www.rrac.info/) in 2003. The idea is to administer normalized and increasing doses of AVK to rodents (as multiples of a known effective dose 50 for which $50 \%$ of the animals treated will have an INR $>5$, in which the INR is a standardized ratio for the measurement of the prothrombin time). Table 5 below gives a list of ED50s of various AVKs in the Norway rat and the House mouse for resistance investigation. 


\begin{tabular}{|c|c|c|c|}
\hline Species / strain & AVK & Gender & ED50 (mg/kg) \\
\hline \multirow{18}{*}{ R. norvegicus (CD) } & \multirow{2}{*}{ Warfarin } & $\mathrm{M}$ & 1.51 \\
\hline & & $\mathrm{F}$ & 2.13 \\
\hline & \multirow[t]{2}{*}{ Diphacinone } & M & 0.86 \\
\hline & & $\mathrm{F}$ & 1.12 \\
\hline & \multirow[t]{2}{*}{ Chlorophacinone } & M & 0.54 \\
\hline & & $\mathrm{F}$ & 0.67 \\
\hline & \multirow[t]{2}{*}{ Coumatétralyl } & M & 0.36 \\
\hline & & $\mathrm{F}$ & 0.44 \\
\hline & \multirow[t]{2}{*}{ Bromadiolone } & M & 0.47 \\
\hline & & $\mathrm{F}$ & 0.61 \\
\hline & \multirow[t]{2}{*}{ Difenacoum } & M & 0.65 \\
\hline & & $\mathrm{F}$ & 0.79 \\
\hline & \multirow[t]{2}{*}{ Difethialone } & M & 0.43 \\
\hline & & $\mathrm{F}$ & 0.49 \\
\hline & \multirow[t]{2}{*}{ Flocoumafen } & M & 0.29 \\
\hline & & $\mathrm{F}$ & 0.34 \\
\hline & \multirow[t]{2}{*}{ Brodifacoum } & M & 0.22 \\
\hline & & $\mathrm{F}$ & 0.23 \\
\hline \multirow[t]{10}{*}{ M. musculus (CD-1) } & \multirow[t]{2}{*}{ Bromadiolone } & M & 1.96 \\
\hline & & $\mathrm{F}$ & 1.68 \\
\hline & \multirow[t]{2}{*}{ Difenacoum } & M & 0.85 \\
\hline & & $\mathrm{F}$ & 0.56 \\
\hline & \multirow[t]{2}{*}{ Difethialone } & M & 0.83 \\
\hline & & $\mathrm{F}$ & 0.83 \\
\hline & \multirow[t]{2}{*}{ Flocoumafen } & M & 0.51 \\
\hline & & $\mathrm{F}$ & 0.44 \\
\hline & \multirow[t]{2}{*}{ Brodifacoum } & M & 0.39 \\
\hline & & $\mathrm{F}$ & 0.35 \\
\hline
\end{tabular}

Table 5. ED50's of various AVKs in susceptible strains of Norway rat (Rattus norvegicus) and House Mouse (Mus musculus) (adapted from RRAC, 2003).

This approach gives phenotypic results and a good idea of the general resistance status of a given strain, both in terms of molecules and level of resistance ( a "resistance factor" can be computed for each AVK tested and is a reliable estimate of the potential efficacy of an AVK), in 24hours. Its limitations are still similar to the feeding test, i.e. manipulation of livetrapped animals, sanitary and ethical problems with the manipulation of wild mammals. It is very commonly used nowadays.

- the second approach has been less developed and investigates the rat vitamin $\mathrm{K}$ deficiency status (Martin et al., 1979). 


\subsubsection{VKOR activity}

Numerous studies have reported the determination of kinetic constants and/or enzyme activity for VKOR in susceptible and resistant rats. Several protocols may be used (Lasseur et al., 2005 ; Lasseur et al., 2007) on liver microsomes or any other enzyme system (recombinant cells for instance as in Rost et al., 2009). This assay can be conducted on a limited number of animals and does not require extensive rodent trapping. Also, animals do not need to be maintained in laboratory facilities. This approach provides a very good estimate of the enzyme activity and the resistance status of a population. It is also rapid and cost-effective, and all AVKs can be tested in a very short time period (Lasseur et al., 2006). This determination requires analytical material (HPLC or LC-MS) for routine determination. Only a few strains will not respond to this assay : metabolic resistance will not be detected, for instance.

\subsubsection{CYP metabolism}

Although CYP metabolism of warfarin in the Norway rat (Ishizuka et al., 2006), in the roof rat (Sugano et al., 2001; Ishizuka et al., 2006) and in the House Mouse (Sutclife, 1990), it is not a standard tool for the monitoring of resistance so far. More work needs to be done to determine the CYP450 isoforms involved, as well as the AVK concerned, in order to develop this approach as a routine monitoring tool for metabolic resistance in rodent species. Undoubtedly, this resistance pathway needs to be more deeply investigated at that point. Nevertheless, it is an in vitro approach, like the VKOR activity assay, and requires microsoms and analytical devices to look at warfarin metabolites produced.

\subsubsection{Vkorc1 sequencing or genotyping}

This last in vitro approach has been suggested in our work (Grandemange et al., 2010). Basically, sequencing of Vkorc1 only requires a piece of animal tissue (tail, ear, fur may be used) and does not necessitate live-trapping of rodents. In the Norway rat, considering the major importance of the SNPs' identified so far, sequencing of Vkorc1 appears as one of the most interesting and cost effective tools to date. As compared with other resistance detection assays, it can be applied rapidly on large scale samples, even across a country (Grandemange et al., 2010). Coupled with VKOR activity measurement in recombinant cells, it can also provide a good indication of the resistance level conveyed by a given mutation. The following primers have been used in the rat: rat VKORC1 exon 1 (VKORC1 GenBank accession no. NM-203 335) are exon1-forward 5' -GTGGCGGGTTCTTCCCTC-3' ) and exon1-reverse primer (5'-GACTCCAAAATCATCTGGCAACC-3' ).

In very specific situations, especially when only one mutation is expected or known to occur, this approach may be simplified even further with the use of qPCR and specific primers. In this case, the different genotypes (homozygous, heterozygous, resistant and susceptible) are tested and their characteristic cycle threshold values $(\Delta \mathrm{Ct}$, i.e. the difference between the matched and the mismatched primer extension for homozygous rats and the absence of such a difference in $\mathrm{Ct}$ values for heterozygous animals) gives significantly different results (see figure 6).

This last approach is the most cost-effective one when the resistance status of a population is known. It is used extensively in our group to investigate wild populations of rats, since the Y139F mutation is the only SNP detected so far in our study sites. Nevertheless, a similar approach can be conducted with specific primers for each SNP and the results combined. 
Only very small pieces of tissue are required and we have evidence that this technique can be applied to fecal samples, which are extremely common and easy to collect when rat populations are installed.
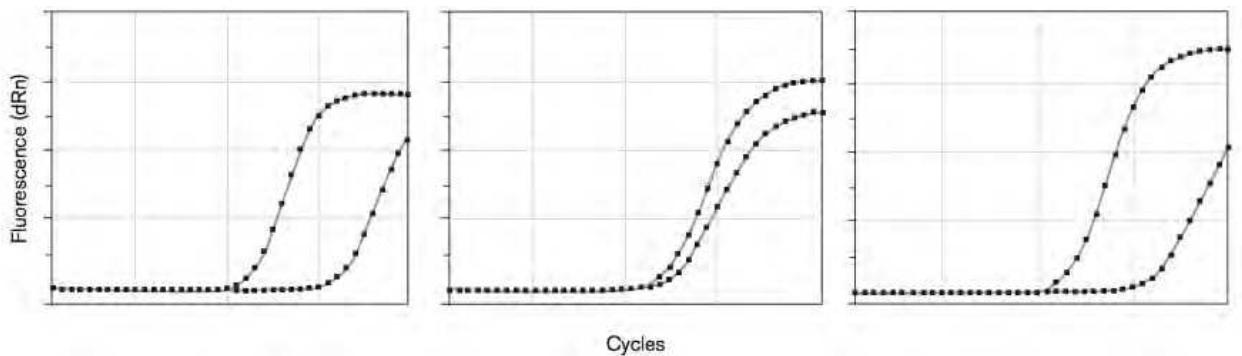

Fig. 6. Fluorescence and qPCR determination of the genotype of Norway rats (for the Y139F mutation). The first graph represents the SYBER green fluorescence curves for a SD/SD animal, with a cycle threshold (DCt) of -9.28 cycles, the second graph represents the SYBER green fluorescence curves for a SD/Y139F animal, with a DCt of 0.91 cycles and the third graph represents the SYBER green fluorescence curves for a Y139F/Y139F animal, with a DCt of 9.83 cycles. $\mathrm{dRn}$, baseline corrected normalized fluorescence (adapted from Grandemange et al., 2009)

\subsubsection{Management of resistance}

When resistance is confirmed in a given population, a proper strategy needs to be implemented, in order to avoid spreading of this resistance and over selection of hyper resistant individuals.

A first step (if we exclude construction and rodent-proofing techniques) is to place baits judiciously to facilitate regular and massive uptake by rodents. Endepols et al. (2003) clearly showed that each site needs to be visited and baiting must be carefully planned in order to achieve excellent baiting results and to overcome resistance. Similarly, Whisson and Salmon (2002) showed that, in another rodent species, bait uptake does not need to be continuous (even one feeding every $48 \mathrm{~h}$ is sufficient to result in death) but well planned and with adapted baits (good palatability).

In the EU, AVKs are the only chemical option against rats. Therefore, it is impossible to switch to another family of rodenticide as can be done with insecticides for instance (http://www.rrac.info/). In mice, this is still an option to consider.

The RRAC suggests to avoid permanent baiting with AVKs and to use them only when rodent infestation is observed. Bait station and boxes should be replenished as needed (every day or every other day) until consumption is no longer detected. Then all baits should be removed.

One important issue still unresolved is the choice of active AVK to use. Indeed, the Danish situation, in which warfarin, then coumatetralyl, followed by difenacoum have been used successively, shows that this progressive strategy has resulted in extremely high levels of resistance of rats, even to difenacoum, in most of the country (Lodal, 2001). The opposite strategy would then appear to be a major shift towards newer second generation AVKs (brodifacoum, difethialone for instance), hoping that moving from chlorophacinone or warfarin to one of these AVKs represents a change that cannot result in an adaptation of the 
rat population. We have tested (unpublished results) such a situation, and there seems to be a dramatic increase in the proportion of homozygous resistant animals in the resulting population. However, lowering AVK selection pressure results in a rapid return of susceptible individuals, thereby suggesting that there is a real biological cost associated with the resistance status and therefore resistant individuals remain only as long as AVK selection pressure is high. Lodal (2001) and Quy et al. (1995) suggest that second generation AVKs should be used first as a treatment against well-established rodent populations. Then, as prevention, first generation AVKS, especially if no resistance is suspected.

In any case, several strategies need to be evaluated more completely in order to be considered for general application. One major disadvantage of this many strategies is certainly the use of second generation AVKs, which are obviously more toxic and may have more severe detrimental effects on non-target species.

As already advocated by Pelz et al. (2005) and ourselves (Grandemange et al., 2010), testing for resistance in the Norway rat should be considered as much as possible before starting a baiting campaign, since genetic tools are available, easy to use in lab situations and provide rapid answers to customers, in order to decide which AVK should be used.

\section{Ecotoxicity of rodenticides}

When we consider the AVK family, one striking characteristic is that development has always led, so far, to newer, more potent and more persistent compounds, which is by no means acceptable for ecological reasons (Lasseur et al., 2006). AVKs are quite unique because they have a common mode of action and, as a consequence, all AVKs share the clinical features of poisoning with severe bleeding and coagulopathy (Kolf-Clauw et al, 1995). . The only differences of interest are the toxic doses and potential for secondary poisoning.

\subsection{Primary toxicity in non-target species}

Primary poisoning is the result of direct exposure to the toxic bait. Several reviews are available on that topic. Petterino and Paolo (2001) published a paper providing many toxic doses in domestic or laboratory animal species. Watt et al. (2005) also provided a general toxicology paper on human toxicity of AVKs. Recently, we published a survey of AVK poisoning in human beings, domestic and wild animals based on poison control center data (Berny et al., 2010). Human exposure is fairly limited, thanks to the use of bittering agents and the vast majority of AVK exposure in humans result in no clinical signs. Only suicidal attempts may result in severe poisoning cases, but, generally speaking, AVK exposure in humans does not result in prolonged surveillance of patients (Caravatti et al., 2007) The high frequency of rodenticide primary poisoning in companion animals is fairly widespread across Europe and the US (Roben et al., 1998, Guitart et al., 2010a, Guitart et al., 2010b). Most cases involve dogs, although cats may sometimes be affected as well (Kohn et al., 2003). A summary of the major toxicity data is provided in Table 6 below.

The values reported show the wide variability of toxicity for each AVK across species. Nevertheless, some surprising results need to be considered. For instance, chlorophacinone appears to be moderately toxic. Indeed, the lowest reported LD50 In the dog is $50 \mathrm{mg} / \mathrm{kg}$. Considering the amount available in most baits in the EU (50 to $75 \mathrm{mg} / \mathrm{kg}$ bait), a 10-kg dog would need to eat $6.6 \mathrm{~kg}$ bait to reach this LD50. Even considering $1 / 10^{\text {th }}$ of this dose still potentially lethal, the same dog would still need to eat about $700 \mathrm{~g}$ bait to be poisoned. 
Clinical data reported in our survey are quite opposite to that, since chlorophacinone is one of the most commonly involved AVK in companion animal poisoning (Berny et al., 2010). It is our hypothesis that AVK toxicity may be more pronounced in real case situations, mainly because animals are more active and may suffer from hemorrhages more rapidly than laboratory animals, confined and quiet. A second possibility can be deduced from Table 5 . Warfarin and coumatetralyl, for instance, have very low LD50s' when administered over several days, as compared with acute oral LD50s'. This is probably due to the accumulation of AVKs in the liver. None of the other AVK has been specifically tested to validate this hypothesis but we suggest that repeated exposure (even 2 or 3 times) could significantly reduce the toxic dose necessary to poison a dog and certainly be more consistent with the results of the survey.

\begin{tabular}{|c|c|c|c|c|c|c|c|c|c|}
\hline AVK & Rat & Mouse & G. pig & Rabbit & Dog & Cat & Quail & Chicken & Cattle \\
\hline Warfarin & $\begin{array}{c}186 \\
(1-5 d)\end{array}$ & 374 & - & - & $3(5 d)$ & $3(5 d)$ & $>2150^{\circ}$ & - & $\begin{array}{l}200 \\
(5 d)\end{array}$ \\
\hline Coumatetralyl & $\begin{array}{c}16.5 \\
(0.3-5 d)\end{array}$ & - & $>250$ & $>500$ & - & 50 & 2000 & - & - \\
\hline Bromadiolone & 1.12 & 1.75 & - & 1.0 & 8.1 & $>25$ & 1600 & - & - \\
\hline Difenacoum & 1.8 & 0.8 & 50 & 2.0 & $>50$ & 100 & - & $>50$ & $100^{* *}$ \\
\hline Flocoumafen & 0.25 & 0.8 & $>50^{*}$ & 0.2 & $\begin{array}{c}0.075- \\
0.25\end{array}$ & $>10$ & $>300$ & $>100$ & \\
\hline Brodifacoum & 0.27 & 0.4 & 2.8 & 0.3 & $0.25-1$ & 25 & - & 4.5 & $>3^{* *}$ \\
\hline Difethialone & 0.56 & 1.29 & - & - & 4 & 16 & - & - & - \\
\hline Diphacinone & 2.3 & 340 & - & 35 & $3-7.5$ & 14.7 & $>400^{\circ}$ & - & - \\
\hline $\begin{array}{l}\text { Chlorophaci- } \\
\text { none }\end{array}$ & 6.26 & 1.06 & - & 50 & $50-100$ & - & $258^{\circ}$ & - & - \\
\hline
\end{tabular}

*hamster, ${ }^{* *}$ goat and sheep, ${ }^{\circ}$ Northern Bobwhite quail

Table 6. Toxicity data (acute oral LD50s in mg/ $\mathrm{kg} /$ day) for AVKs in animals (adapted from Petterino and Paolo, 2001, Toxnet ${ }^{\circledR}$ : values in bold+italics and USEPA : values in blue)

Among domestic species, herbivores appear to be absent. A survey at the Animal Poison Control Center (Lyon, France) confirmed that cattle, sheep and goat are rarely affected by AVK poisoning, as compared with other species (Berny et al, 2005). These cases, however, usually involve several animals (mean $=6$ for cattle, 33 for sheep/goat) and raise questions regarding residues of AVK in milk, for which there is no published data. Affected animals develop hemorrhagic disorders (digestive and respiratory mostly). Pre-ruminant animals are usually considered to be more susceptible and, indeed, they are usually more affected (Berny et al., 2005) and sometimes also more exposed (Braselton et al., 1992, Del Piero and Poppenga, 2003). Some cases of AVK poisoning are reported in horses (Guitart et al, 2010a), 
although rarely. Lethal cases are also described with hemorrhages in horses. This seems to occur only with potent, second generation AVKs such as Brodifacoum (Ayala et al., 2007): a pony ingested $c a 2 \mathrm{~kg}$ of a commercial bait, reaching almost $0.8 \mathrm{mg} / \mathrm{kg}$, which is a lethal dose for many species as can be seen in Table 5 .

Questions may also be raised with respect to wildlife. Direct poisoning may occur when baits are applied to extensive areas. This is frequently observed in rodent eradication campaigns, for instance, when aerial application or wide application of AVKs is considered. Thorsen et al. (2000) have evaluated the consequences of brodifacoum application in the Seychelles archipelago and discuss the cost/benefit ratio. In a more generalized view, Howald et al. (2007) reviewed the invasive rodent eradication campaigns in islands and showed that the use of tampered bait stations could successfully reduce primary non-target poisoning. Many species can be affected, depending on the bait nature. One can cite hares, rabbits (Erickson and Urban, 2002), roe deers, wild boars (Berny et al., 2005). In wildlife, however, primary poisoning is not a major issue and most concern is raised by secondary poisoning.

\subsection{Secondary toxicity}

Secondary poisoning is quite unique to AVKs and can be defined as clinical poisoning occurring in predators and scavengers feeding on contaminated preys. Fairly soon after AVKs started to be used, secondary poisoning was considered as a potential adverse effect of these compounds. Cases of warfarin secondary poisoning are reported by Bentley (1972) in dogs fed poisoned Coypu. At that time, the author concluded that warfarin should not be used to control coypu invasive populations in Florida for this reason. It was not until second-generation AVKs were marketed that secondary poisoning was given full attention. Evidence was published by Gray et al. (1994a) that some of the most recent AVKs (namely : brodifacoum, difenacoum, flocoumafen) were experimentally responsible for secondary poisoning in Barn owls (Tyto alba). This first trial, however, only showed that owls fed contaminated mice over 15 days would accumulate AVK residues in the liver, considered as the primary target organ for accumulation. This information was used in surveys that started soon afterwards to be published. For instance, evidence of secondary poisoning was confirmed in red foxes (Vulpes vulpes) and buzzards (Buteo buteo) (Berny et al., 1997), but also in non-target native species in New-Zealand (Eason et al., 2002). Liver samples were used as an indicator of AVK exposure in animals found dead. AVKs are very specific in that their clinical and pathological features are fairly similar across species and animals always die of hemorrhages. Gross necropsy is usually indicative of AVK poisoning with evidence of massive hemorrhages and lack of coagulation (Berny et al., 2007). There is evidence that vitamine $\mathrm{K}$ may play a role in bone metabolism and humans exposed to prolonged AVK therapy may experience increased frequency of bone fractures and osteoporosis. In wildlife species exposed to AVKs, there is, as of to day, no evidence that this is the case, but only one study has been dealing with this issue so far (Knopper et al., 2007). In the UK, small mustelids also were detected with secondary AVK poisoning (Shore et al., 1999). These first reports clearly confirmed the high susceptibility of canids and birds of prey to AVK rodenticides. In some instances, critically endangered sand protected species may be concerned and unexpected death from AVK exposure may be dramatic, such as shown for the Red kite (Milvus milvus) (Berny and Gaillet, 2008). Some unusual species such as the Otter (Lutra lutra) and the European mink (Mustela vison) have also been found to be 
exposed to AVKs (Fournier-Chambrillon et al., 2004), with reference to the use of AVK against coypu in wetlands in France.

More generalized surveys have also been conducted on animals found dead and submitted to a diagnostic laboratory. Several publications and countries now report a high prevalence of AVK exposure (i.e. detection of AVK, with or without evidence of poisoning). This is the case in birds of prey from New York (Stone et al., 2003), who showed that $49 \%$ of the 265 animals analyzed contained detectable residues of AVKs in the liver. Similarly, in a survey conducted on 58 birds received dead at a rehabilitation center in France (Lambert et al., 2007), 73\% of the animals contained detectable residues. In Great Britain, a survey on Tawny owls (Walker et al., 2008 ) also indicated a high prevalence of AVK exposure $(>20 \%)$, very stable over time. In Canada, there is also evidence that owl species are highly exposed to AVK rodenticides (Albert et al., 2010). More recently, even insectivores such as the Hedgehog have been shown to accumulate AVK to significant extent (Dowding et al., 2010). Probably the most severe contamination appears to be in Californian Mountain Lions (Puma concolor) and bobcats (Lynx rufus), since almost $90 \%$ of them have been found with residues (Riley et al., 2007). The authors even consider the interaction of AVK exposure with the development of other diseases such as a parasitic infestation with notoedric mange in this case.

Secondary poisoning is certainly a result of the prolonged half-life of most AVKs in biological fluids and tissues, as can be seen in Table 6 .

\begin{tabular}{|c|c|c|c|c|c|c|c|c|}
\hline AVK & $\begin{array}{l}\text { Rat- } \\
\text { blood }\end{array}$ & $\begin{array}{l}\text { Dog- } \\
\text { blood }\end{array}$ & $\begin{array}{l}\text { Sheep- } \\
\text { blood }\end{array}$ & $\begin{array}{l}\text { Rabbit- } \\
\text { blood }\end{array}$ & $\begin{array}{l}\text { Rat- } \\
\text { liver }\end{array}$ & $\begin{array}{l}\text { Dog- } \\
\text { liver }\end{array}$ & $\begin{array}{l}\text { Sheep- } \\
\text { liver }\end{array}$ & $\begin{array}{l}\text { Rabbit- } \\
\text { liver }\end{array}$ \\
\hline Warfarin & $\begin{array}{l}0.7-1.2 \\
14.9^{\circ 0}\end{array}$ & & 9.5 & 0.2 & $66.8^{\circ 0}$ & - & - & - \\
\hline Coumatetralyl & $0.5^{\circ \circ}$ & - & - & - & $15.8^{\circ 0}$ & - & - & - \\
\hline Bromadiolone & $\begin{array}{c}1-2.4 \\
33.3^{\circ 0}\end{array}$ & $12.7-72.2 \dagger$ & 49.5 & - & $\begin{array}{c}170-318 \\
28.1^{\circ 0}\end{array}$ & - & $256^{*}$ & - \\
\hline Difenacoum & $20.4^{\circ \circ}$ & - & - & - & $61.8^{\circ 0}$ & - & - & - \\
\hline Flocoumafen & $26.6^{\circ 0}$ & - & - & - & $93.8^{\circ 0}$ & - & - & - \\
\hline Brodifacoum & $\begin{array}{c}6.5 \\
91.7^{\circ 0}\end{array}$ & $0.9-4.7$ & - & 2.5 & $\begin{array}{c}128-350 \\
307^{\circ}\end{array}$ & - & $>128^{*}$ & - \\
\hline Difethialone & $\begin{array}{c}2.3 \\
38.9^{\circ 0}\end{array}$ & $2.2-3.2$ & - & - & $\begin{array}{l}74-126 \\
28.5^{\circ 0}\end{array}$ & - & - & - \\
\hline Diphacinone & & - & - & - & - & - & $>90 * 0$ & - \\
\hline Chlorophacinone & $\begin{array}{c}0.4 \\
11.7^{\circ \circ}\end{array}$ & - & 30.1 & - & $35.4^{\circ 0}$ & - & - & - \\
\hline
\end{tabular}

*estimated liver retention in days, ${ }^{\circ}$ cattle, ${ }^{\circ}$ mouse, in days, tin the red fox

from Erickson and Urban, 2002, Robben et al., 1998, Berny et al., 2006, Vandenbroucke et al., 2008a, Sage et al, 2010

Table 6. Half-lives of selected AVKs in plasma (h) and liver (days) of various species. 
Despite some discrepancies, probably due to different analytical techniques and sampling times, the general trend points out the prolonged liver retention of second generation AVKs.

\begin{tabular}{|c|c|c|c|c|c|c|c|}
\hline Species & $\mathrm{N}$ & COUMAT & CHLORO & BRODIF & BROMA & DIFEN & FLOCOUM \\
\hline $\begin{array}{l}\text { Hedgehog } \\
\text { (Erinaceus } \\
\text { europaeus) }\end{array}$ & 120 & - & - & 3,3 & 10,8 & 13,3 & 0 \\
\hline $\begin{array}{l}\text { Polecat } \\
\text { (Mustela } \\
\text { putorius) }\end{array}$ & 100 & - & - & 3,0 & 12,0 & 22,0 & 0 \\
\hline $\begin{array}{l}\text { Stoat } \\
\text { (Mustela } \\
\text { erminea) }\end{array}$ & 40 & 15,0 & - & 2,5 & 6,7 & - & - \\
\hline $\begin{array}{l}\text { Weasel } \\
\text { (Mustela nivalis) }\end{array}$ & 10 & 30,0 & - & - & 10,0 & - & - \\
\hline $\begin{array}{l}\text { Red fox (Vulpes } \\
\text { vulpes) }\end{array}$ & 92 & 7,6 & - & 5,4 & 26,1 & 16,3 & - \\
\hline Ref Fox (F) & 62 & 0 & 4,8 & 0 & 12,9 & 1,6 & 0 \\
\hline $\begin{array}{l}\text { Barn owl (Tyto } \\
\text { alba) }\end{array}$ & 717 & - & - & 3,9 & 11,0 & 16,7 & 1,1 \\
\hline $\begin{array}{l}\text { Buzzard (Buteo } \\
\text { buteo) }\end{array}$ & 40 & - & - & 2,5 & 5 & 32,5 & 2,5 \\
\hline Buzzard (F) & 98 & 0 & 5,1 & 0 & 14,2 & 0 & 0 \\
\hline $\begin{array}{l}\text { Red kite } \\
\text { (Milvus milvus) }\end{array}$ & 20 & - & - & - & 1,2 & - & 0 \\
\hline Red kite $(\mathrm{F})$ & 62 & 0 & 4,8 & 0 & 38,7 & 0 & 0 \\
\hline
\end{tabular}

Coumat $=$ coumatetraly, Chloro $=$ chlorophacinone, Brodif $=$ Brodifacoum, Broma $=$ Bromadiolone, Difen

$=$ Difenacoum, Flocoum $=$ Flocoumafen

* completed from Dowding et al., 2010

Table 7. Proportion of animals with detectable residues in France (F) and in the UK (in\%)*

These data clearly confirm that secondary poisoning with AVKs is not a theoretical problem. In a review paper on island preservation and rodent eradication, Howald et al. (2007) obviously confirm that secondary poisoning occurs regularly after aerial or general bait application, but they also show that, generally speaking, the local population recovers shortly after bait removal. As a general overview, Table 7 describes the proportion of animals detected with AVK residues in France and the UK, based on published data (Dowding et al., 2009) and unpublished data (France). These results clearly point out the high frequency of detection of residues of AVKs despite limited outdoor use in the UK and restricted used in France.

Studies on secondary poisoning have been possible because of the rapid evolution of analytical techniques. Today, many LC-MS-MS techniques are available to detect minute amounts of AVKs in various biological samples such as the liver, plasma or fecal samples (Jin et al., 2008, Vandenbroucke et al., 2008b, Fourel et al., 2010 ; Sage et al., 2010, Vudathala et al., 2010). We have even shown that non-invasive monitoring, as already suggested by Gray et al (1994) on pellets of birds of prey could easily use fecal samples of foxes for instance: it is possible to confirm exposure even one month after the last ingestion of a 
contaminated prey (Sage et al., 2010). Using this approach could certainly improve our knowledge of AVK exposure in non-target predators and be used as monitoring tools for wide-scale surveys. This would certainly be of help, in order to monitor potential exposure, since there is evidence that AVK user behavior could still improve to reduce unnecessary exposure of non-target species (Tosh et al., 2011).

The question of concern remains of the long-term impact of such a bottleneck in genetics. Instead of facing such an adverse effect in non-target species, some authors consider alternatives to the use of AVKs (Donlan et al., 2003).

\section{Conclusions - perspectives}

AVKs have considerably changed our practice and perspectives for rodent control. Unfortunately, the intensive use of these compounds has been rapidly followed by the development of resistant strains in Norway rats, roof rats and house mice. These resistant strains have developed specific genetic traits either via a modification of the VKOR enzyme involved in the catalytic cycle of vitamin $\mathrm{K}$ or via metabolic profile modification via induction and overexpression of selected CYP450 isoforms. The most widely spread resistance mechanism appears to be related to VKOR alteration and specifically SNPs in vkorc1 gene. As of today, however, very little is known of the effects of these mutations on the enzyme activity and, similarly, the biological cost of these mutations and resistance is not known.

In order to overcome AVK resistance, second generation compounds have been developed. These compounds are more toxic and more persistent and, therefore, can be successfully used when resistance to first generation AVK is suspected. As a consequence, non-target poisoning is more common, especially secondary poisoning of predators and scavengers. In some instances, endangered species may even be critically affected, although eradication programs in islands have usually shown that most species promptly recover if the eradication campaign is short. This secondary poisoning issue has been raised to a new level by recent surveys showing that many different species (mammals and birds) contain detectable residues of AVKs in various organs, at low levels but still of concern, raising the question of when and where animals have been exposed.

There is some debate as to whether these compounds should be banned. This issue has no easy answer, considering the two problems developed above, but also there are no other chemicals of help, with the advantages of AVKs (specific antidote, delayed poisoning) and many countries, especially in Europe, do not consider any other option for the time being. A valid possibility would be, based on enzymatic and ecotoxicology evaluation, to develop AVK compounds with a strong affinity for the enzyme and a short residence time, in order to avoid secondary poisoning, but no publication has developed that topic recently.

\section{Acknowledgements}

The author wishes to thank all Resistance Team of INRA-Vetagro sup USC1233.

\section{References}

Albert, C., Wilson, L., Mineau, P., Trudeau, S., \& Elliott, J. (2010). Anticoagulant Rodenticides in Three Owl Species from Western Canada, 1988-2003. Archives of Environmental Contamination and Toxicology , 58 (2), 451-459. 
Alessandroni, P., Marchini, S., Bernardo, A., Terranova, F., Turillazi, P. (1980). Valutazione della presenza di ratti resistenti al warfarin nella cita di reggio Calabria. Ann. $1^{\text {st }}$ Super Sanita, 16: 271-286.

Ayala, I., Rodríguez, M., Martos, N., \& Zilberschtein, J. (2007). Fatal brodifacoum poisoning in a pony. The Canadian Veterinary Journal . $48: 627-629$

Baert, K. (2003). Bestrijding van de Bruine rat. Resistentie tegen anticoagulantia bij de Bruine rat. In: IBW (ed.). Jaarrapport-Onderzoeksgroep Rattenbestijding. AMINAL afdeling Water, IBW, Geraardsbergen, 18-23.

Bentley, E. (1972). A review of anticoagulant rodenticides in current use. Bulletin of the World Health Organization, 47 (3), 275-80.

Berny, P., Buronfosse, T., Buronfosse, F., \& Lamarque, F. (1997). Field evidence of secondary poisoning of foxes (Vulpes vulpes) and buzzards (Buteo buteo) by bromadiolone : a 4-year survey. Chemosphere 35 (8) : 1817-1829

Berny, P, Alves, L., Simon V., \& Rossi, S. (2005) Intoxication des ruminants par les raticides anti-coagulants: quelle réalité? Revue de médecine vétérinaire 156, (8-9): 449-454.

Berny, P, Alves de Oliveira L., Videmann, B., \& Rossi S. (2006) Assessment of ruminal degradation, oral bioavailability, and toxic effects of anticoagulant rodenticides in sheep. American Journal of Veterinary Research 67 (2) : 363-371

Berny, P. (2007). Pesticides and the intoxication of wild animals. Journal of Veterinary Pharmacology and Therapeutics. 30 : 93-100

Berny, P., \& Gaillet, J.-R. (2008). Acute poisoning of Red Kites (Milvus milvus) in France: Data from the SAGIR network. Journal Of Wildlife Diseases , 44 (2), 417-426.

Berny, P., Velardo, J., Pulce, C., D’Amico, A., Kammerer, M., \& Lasseur, M (2010a) Prevalence of anticoagulant rodenticide poisonings in humans and animals in France and substances involved. Clinical Toxicology, 48 : 935-941

Bonnefoy, X., Kampen, H., \& Sweeney, K. (2008). Public Health Significance of Urban Pests. 1-292.

Boyle, C. (1960). Case of apparent resistance of Rattus norvegicus Berkenhout to anticoagulant poisons. Nature 188: 517-525

Braselton, W., Regg, D., \& Poppenga, R. (1992). Confirmation of indanedione rodenticide toxicoses by mass spectrometry/mass spectrometry. J. vet. Diagn. Invest. , 4, 441446.

Brooks, J., \& Bowerman, A. (1973). Anticoagulant resistance in wild Norway rats in New York. The Journal of hygiene, 71 (2), 217-22.

Caravatti, E.M., Erdman, A.R., Scharman, E.J., Woolf, A.D., Chyka, P.A., Cobaugh, D.J., Wax, P.M., Manoguerra, AS., Christianson, G., Nelson, L.S., Olson, K.R., Booze, L.L., Troutman, W.G. (2007) Long-acting anticoagulant rodenticide poisoning: an evidence-based consensus guideline for out-of-hospital management. Clin Toxicol 42: $1-22$

De Jonge, J. (1994). Resistentieproblemen bij de bestrijding van knaagdieren in Nederland. Dierplagen en Milieu 42: 99-101

Del Piero, F., \& Poppenga, R. (2006). Chlorophacinone exposure causing an epizootic of acute fatal hemorrhage in lambs. Journal of Veterinary Diagnostic Investigation 18 : 483-485

Díaz, J., Song, Y., Moore, A., Borchert, J., \& Kohn, M. (2010). Analysis of vkorc1 polymorphisms in Norway rats using the roof rat as outgroup. BMC genetics, 11, 43. 
Donlan, C., Howald, G., Tershy, B., \& Croll, D. (2003). Evaluating alternative rodenticides for island conservation: roof rat eradication from the San Jorge Islands, Mexico Biological Conservation 114 : 29-34

Dowding, C., Shore, R., Worgan, A., Baker, P., \& Harris, S. (2010). Accumulation of anticoagulant rodenticides in a non-target insectivore, the European hedgehog (Erinaceus europaeus). Environmental pollution (Barking, Essex : 1987), 158 (1), 161-6.

Drummond, D., \& Rennison, B. (1973). The detection of rodent resistance to anticoagulants. Bulletin of the World Health Organization, 48 (2), 239-42.

Eason, C. T., Murphy, E.C., Wright, G. R. \& SPURR, E.B. (2002). Assessment of risks of brodifacoum to non-target birds and mammals in New- Zealand. Ecotoxicology 11: $35-48$

Endepols, S., Klemann, N., Pelz, H., \& Ziebell, K. (2003). A scheme for the placement of rodenticide baits for rat eradication on confinement livestock farms. Preventive Veterinary Medicine 58 : 115-123

Erickson, W., \& Urban, D. (2002). Comparative Rodenticide Risk Assessment pp1-202. United States Environmental Protection Agency, Washington DC

Fasco, M., Principe, L. (1982). R- and S-Warfarin inhibition of vitamin K and vitamin K 2,3epoxide reductase activities in the rat. J. biol. Chem. 257, (9): 4894-4901

Fourel, I., Hugnet, C., Goy-Thollot, I., \& Berny, P. (2010). Validation of a new liquid chromatography- tandem mass spectrometry ion-trap technique for the simultaneous determination of thirteen anticoagulant rodenticides, drugs, or natural products. Journal of Analytical Toxicology , 34 (2), 95-102.

Fournier-Chambrillon, C., Berny, P., Coiffier, O., Barbedienne, P., Dassé, B., Delas, G., Galineau, H., Mazet, A., Pouzenc, P., Rosoux, R., \& Fournier, P. (2004). Evidence of secondary poisoning of free-ranging riparian mustelids by anticoagulant rodenticides in France: implications for conservation of European mink (Mustela lutreola). Journal of Wildlife Diseases , 40 (4), 688-695.

Gill, J., MacNicoll, A. (1991). Determination of the susceptibility of wild populations of Norway rat (Rattus norvegicus) to the anticoagulant rodenticide brodifacoum. Z . Fuer Angewandte Zool. 78: 101-117.

Grandemange, A., Kohn, M., Lasseur, R., Longin-Sauvageon, C., Berny, P., \& Benoit, E. (2009). Consequences of the Y139F Vkorc1 mutation on resistance to AVKs: in-vivo investigation in a 7 th generation of congenic Y139F strain of rats. Pharmacogenetics and Genomics , 19 (10), 742.

Grandemange, A., Lasseur, R., \& Longin- ..., C. (2010). Distribution of VKORC1 single nucleotide polymorphism in wild Rattus norvegicus in France Pest management 66 (3) : 270-276

Gray, A., Eadsforth, C., Dutton, A., \& Vaughan, J. (1994). The toxicity of three secondgeneration rodenticides to barn owls. Pesticide Science, 42 (3).

Greaves, J., \& Ayres P. (1967). Heritable resistance to warfarin in rats. Nature 215: 877-878

Greaves, J., \& Ayres, P. (1973). Warfarin resistance and vitamin K requirement in the rat. Laboratory animals , 7 (2), 141-8.

Greaves, J., Sheperd, D., Gill, J. (1982). An investigation of difenacoum resistance in the norway rat populations in Hampshire. Ann. appl. Biol. 100: 581-587

Guidobono, J., León, V., Gómez Villafañe, I., \& Busch, M. (2010). Bromadiolone susceptibility in wild and laboratory Mus musculusL.(house mice) in Buenos Aires, Argentina. Pest Management Science, 66 : 162-167. 
Guitart, R., Croubels, S., Caloni, F., Sachana, M., Davanzo, F., Vandenbroucke, V., \&Berny, P (2010a). Animal poisoning in Europe. Part 1: Farm livestock and poultry. The Veterinary Journal , 183, (3) : 249-254

Guitart, R., Sachana, M., Caloni, F., Croubels, S., Vandenbroucke, V., \& Berny, P. (2010b). Animal poisoning in Europe. Part 3: Wildlife. Veterinary journa , 183 (3) : 260-265.

Heiberg, A. (2009). Anticoagulant resistance: a relevant issue in sewer rat (Rattus norvegicus) control? Pest. Management Scie. 65 : 444-449

Heiberg, A.-C., Leirs, H., \& Siegismund, H. (2006). Reproductive success of bromadioloneresistant rats in absence of anticoagulant pressure. Pest Management Science, 62 (9), 862-871.

Hermodson, M. A., Suttie, J. W. \& Link, K. P. (1969). Warfarin metabolism and vitamin K requirement in the warfarin-resistant rat. American Journal of Physiology 217 : 13161319

Howald, G., Donlan, C., Galván, J., Russell, J., Parkes, J., Samaniego, A., Wang, Y., Veitch, D., Genovesi, P., Pascal, M., Sanuders, A., Tershy, B. (2007). Invasive rodent eradication on islands. Conservation Biology , 21 (5), 1258-68.

Ishizuka, M., Okajima, F., Tanikawa, T., Min, H., Tanaka, K., Sakamoto, K., et al. (2006). Elevated Warfarin Metabolism in Warfarin-Resistant Roof Rats (Rattus rattus) in Tokyo. Drug Metabolism and Disposition, 35 (1), 62-66.

Ishizuka, M., Tanikawa, T., Tanaka, K., \& Heewon, M. (2008). Pesticide resistance in wild mammals-Mechanisms of anticoagulant resistance in wild rodents. The Journal of Toxicological Sciences 33 (3) : 283-291

Jackson, W., Ashton, A. (1986). Case histories of anticoagulant resistance. In: Committee on strategies for the management of pesticide resistant pest populations, National Research Council (eds). Pesticide resistance: strategies and tactics for management, National Academy Press, Washington pp: 335-369.

Jin, M., Chen, X., Ye, M., \& Zhu, Y. (2008). Analysis of indandione anticoagulant rodenticides in animal liver by eluent generator reagent free ion chromatography coupled with electrospray mass spectrometry. Journal of Chromatography A , 1213 (1), 77-82.

Knopper, L., Mineau, P., Walker, L., \& Shore, R. (2007). Bone Density and Breaking Strength in UK Raptors Exposed to Second Generation Anticoagulant Rodenticides Bulletin of Environmental Contamination and Toxicology 78 : 249-251

Kohn, B., Weingart, C., \& Giger, U. (2003). Haemorrhage in seven cats with suspected anticoagulant rodenticide intoxication. Journal of Feline Medicine and Surgery 5: 295304

Kolf-Clauw, M., Alvarez, E., Maytray, O. (1995). Anticoagulants rodenticides: étiologie, diagnostic et traitement des intoxications. Rec. Méd. vét. 171, 2/3: 127-134

Lambert, O., Pouliquen, H., Larhantec, M., Thorin, C., \& L'Hostis, M. (2007). Exposure of raptors and waterbirds to Anticoagulant Rodenticides (Difenacoum, Bromadiolone, Coumatetralyl, Coumafen, Brodifacoum): epidemiological survey in Loire Atlantique (France) Bulletin of Environmental Contamination and Toxicology 79: $91-94$

Lasseur, R., Grandemange, A., \& Longin-Sauvageon, C. (2007). Comparison of the inhibition effect of different anticoagulants on vitamin $\mathrm{K}$ epoxide reductase activity from warfarin-susceptible and resistant rat. Pesticide Biochemistry and Physiology 88 : 203208

Lasseur, R., Grandemange, A., Longin-Sauvageon, C., Berny, P., \& Benoît, E. (2006). Heterogeneity of the coumarin anticoagulant targeted vitamin $\mathrm{K}$ epoxide reduction 
system. Study of kinetic parameters in susceptible and resistant mice (Mus musculus domesticusJ. Biochem. Mol . Toxicol. 20, (5) : 221-229.

Lasseur, R., Longin-Sauvageon, C., \& Videmann, B. (2005). Warfarin resistance in a French strain of rats. J. Biochem. Mol. Toxicol 19 (6) : 379-385

Li, T., Chang, C., Jin, D., Lin, P., Khvorova, A., Stafford, D. (2004). Identification of the gene for vitamin K epoxide reductase. Nature, 427, 541-544.

Leung, L., \& Clark, N. (2005). Bait avoidance and habitat use by the roof rat, Rattus rattus, in a piggery. International Biodeterioration \& Biodegradation 55 : 77-84

Lodal, J. (2001). Distribution and levels of anticoagulant resistance in rat (Rattus norvegicus) in Denmark. In: Peltz, H.J., Cowan, D., Feare, C. (eds). Advances in Vertebrate Pest Management II, Finlander Verlag, Fürth, Germany, 139-148.

Lund, M. (1972). Rodent resistance to the anticoagulant rodenticides, with particular reference to Denmark. Bulletin of the World Health Organization , 47 (5), 611-8.

Lund, M. (1984). Resistance to the second-generation anticoagulant rodenticides. In: Clark, D.O. (ed.). Proceedings of the $11^{\text {th }}$ Vertebrate Pest Conference, Rodent Biology, Davis, California, USA, 23-26 May 1983, Academic Press, New York, p. 89-94.

Markussen, M., Heiberg, A., Alsbo, C., Nielsen, P., Kauppinen, S., \& Kristensen, M. (2007). Involvement of hepatic xenobiotic related genes in bromadiolone resistance in wild Norway rats, Rattus norvegicus (Berk.). Pesticide Biochemistry and Physiology , 88 (3), 284-295.

Markussen, M., Heiberg, A.-C., Nielsen, R., \& Leirs, H. (2003). Vitamin K requirement in Danish anticoagulant-resistant Norway rats (Rattus norvegicus). Pest Management Science, 59 (8), 913-920.

Martin, A., Steed, L., Redfern, R., Gill, J., Huson, L. (1979). Warfarin-resistance genotype determination in the Norway rat, Rattus norvegicus. Lab. Anim. 13 : 209-214

Misenheimer, T., Suttie, J. (1990). Warfarin resistance in a Chicago strain of rats. Biochem. Pharmacol. 40: 2079-2084.

Misenheimer, T., Lund, M., Baker, E.M., Suttie, J. (1993). Biochemical basis of warfarin and bromadiolone resistance in the house mouse, Mus musculus domesticus. Biochem. Pharmacol. 47 (4): 673-678.

Muhr, A. (1981). Zur problematik der Hausmausbekämpfung, resistenzprobleme und Möglichkeiten ihrer Uberwindung. In: Iglisch, I. (ed.). Aktuelle Probleme der Bekämpfung und Abwehr von Ratten und Hausmäusen, Pentagon Publishing GmbH, Frankfurt, 93-109

Myllymaki, A. (1995). Anticoagulant resistance in Europe: appraisal of the data from the 1992 EPPO questionnaire. Pestic. Sci. 43: 69-72.

Naganuma, K., Fukita, A., Taniguchi, N., Takada, S. (1981). Warfarin susceptibility in the roof rat, Rattus rattus, in some locations of Tokyo. Jap. J. sanit. Zool. 32: 243-245

O'Connor, J. (1948). The use of blood anticoagulants for rodent control. Research 1: 334336.

Pelz, H.J., Hanisch, D., Lauenstein, G. (1995) Resistance to anticoagulant rodenticides in Germany and future strategies to control Rattus norvegicus. Pestic. Sci. 43: 61-67.

Pelz, H.J. (2001). Extensive distribution and high frequency of resistance to anticoagulants rodenticides in rat populations from north-western Germany. In: Pelz, H.J., Cowan, D., Feare, C. (eds). Advances in Vertebrate Pest Management volume II, Finlander Verlag, Fürth, Germany, 161-170 
Pelz, J., Rost, S., Hünerberg, M., Fregin, A., Heiberg, A.C., Baert, K., MacNicoll, A., Prescott, C., Walker, A.S., Oldenburg, J., and Müller, C. (2005) The genetic basis of resistance to anticoagulants in rodents. Genetics 170: 1839-1847.

Petterino, C., \& Paolo, B. (2001). Toxicology of Various Anticoagulant Rodenticides in Animals. Veterinary and Human Toxicology 43 (6) : 353-360

Prescott, C., \& Buckle, A. (2000). Blood-clotting response tests for resistance to diphacinone and chlorophacinone in the Norway Rat (Rattus norvegicus, Berk) Crop Protection 19: 291-296

Quy, R., Cowan, D., Prescott, C., Gill, J., Kerins, G., Dunsford, G., Jones, A., MacNicoll, A. (1995). Control of a population of Norway rats resistant to anticoagulant rodenticides. Pest. Sci. 45: 247-256.

Redfern, R., \& Gill, J. (1980). Laboratory evaluation of bromadiolone as a rodenticide for use against warfarin-resistant and non-resistant rats and mice. The Journal of hygiene, 84 (2), 263-8.

Robben, J., Kuijpers, E., \& Mout, H. (1998). Plasma superwarfarin levels and vitamin K1 treatment in dogs with anticoagulant rodenticide poisoning Vet Quarterly 20 : 24-27

Rost, S., Fregin, A., Ivaskevicius, V., Conzelmann, E., Hörtnagel, K., Pelz, H-J., Lappegard, K., Seifried, E., Scharrer, I.,Tuddenham, E., Müller, C., Strom, T., Oldenburg, J. (2004). Mutations in VKORC1 cause warfarin resistance and multiple coagulation factor deficiency type 2. Nature 427: 537-541.

Rost, S., Pelz, H.-J., Menzel, S., Macnicoll, A., Leon, V., Song, K.-J., et al. (2009). Novel mutations in the VKORC1 gene of wild rats and mice - a response to 50 years of selection pressure by warfarin? BMC Genetics , 10 (1), 4.

Sage, M., Fourel, I., Cœurdassier, M., Barrat, J., Berny, P., \& Giraudoux, P. (2010). Determination of bromadiolone residues in fox faeces by LC/ESI-MS in relationship with toxicological data and clinical signs after repeated exposure. Environmental Research 110 (7) : 664-674

Saunders, G. (1978). Resistance to warfarin in the roof rat in Sydney. New South Wales Search, 9: $39-40$

Shore, R., Birks, J., \& Freestone, P. (1999). Exposure of non-target vertebrates to secondgeneration rodenticides in Britain, with particular reference to the polecat Mustela putorius. New Zealand Journal of Ecology 23 (2) : 199-206

Siddiqi, Z., Blaine WD. (1982). Anticoagulant resistance in house mouse in Toronto, Canada. Environ. Health Rev., 26: 49-51.

Stone, W., Okoniewski, J., \& Stedelin, J. (2003). Anticoagulant rodenticides and raptors: Recent findings from New York, 1998-2001. Bulletin of Environmental Contamination and Toxicology $70: 34-40$

Sugano, S., Kobayashi, T., Tanikawa, T., Kawakami, Y., Kojima, H., Nakamura, K., Uchida, A., Morishima, N., Tamai, Y. (2001) Suppression of CYP3A2 mRNA expression in the warfarin-resistant roof rat, Rattus rattus : possible involvement of cytochrome P450 in the warfarin resistance mechanism. Xenobiotica 31: 399-407

Sutcliffe, F., MacNicoll, A., Gibson, G. (1990) Hepatic microsomal warfarin metabolism in warfarin-resistant and susceptible mouse strains: influence of pretreatment with cytochrome P-450 inducers. Chem. biol. Interact 75: 171-184.

Thorsen, M., Shorten, R., Lucking, R., \& Lucking, V. (2000, Jan 1). Norway rats (Rattus norvegicus) on Frégate Island, Seychelles: the invasion; subsequent eradication 
attempts and implications for the Island's fauna Biological Conservation 96: 133138

Tie, J., Nicchitta, C., von Heijne, G., Stafford, D. (2005). Membrane topology mapping of vitamin $\mathrm{K}$ epoxide reductase by in vitro translation/cotranslocation. J. biol. Chem. 280: 16410-16416.

Tosh, D., Shore, R., Jess, S., Withers, A., Bearhop, S., Montgomery, W., et al. (2011, Jan 25). User behaviour, best practice and the risks of non-target exposure associated with anticoagulant rodenticide use. Journal of Environmental Management, 92 (6) : 15031508

Vandenbroucke, V., Bousquet-Melou, A., De Backer, P., \& Croubels, S. (2008). Pharmacokinetics of eight anticoagulant rodenticides in mice after single oral administration. Journal of Veterinary Pharmacology and Therapeutics, 31 (5), 437-445.

Vandenbroucke, V., Desmet, N., Debacker, P., \& Croubels, S. (2008). Multi-residue analysis of eight anticoagulant rodenticides in animal plasma and liver using liquid chromatography combined with heated electrospray ionization tandem mass spectrometry. Journal of Chromatography B , 869 (1-2), 101-110.

Vein J., Grandemange A., Cosson, J.F., Benoît, E., \& Berny P. (in press) Are water voles (Arvicola terrestris) resistant to anticoagulant rodenticides, following field treatments ? Ecotoxicology

Vudathala, D., Cummings, M., \& Murphy, L. (2010). Analysis of multiple anticoagulant rodenticides in animal blood and liver tissue using principles of QuEChERS method. Journal of analytical toxicology, 34 (5), 273-9.

Wajih, N., Sane, D., Hutson, S., Wallin, R. (2004) The inhibitory effect of calumenin on the vitamin K-dependent -carboxylation system. Characterization of the system in normal and warfarin-resistant rats. Biochem. Pharmacol., 279: 25276-25283.

Walker, L., Turk, A., Long, S., Wienburg, C., Best, J., \& Shore, R. (2008). Second generation anticoagulant rodenticides in tawny owls (Strix aluco) from Great Britain. Science of the Total Environment, 392 (1), 93-98.

Wallace, M., \& MacSwiney, F. (1976). A major gene controlling warfarin-resistance in the house mouse. The Journal of hygiene , 76 (2), 173-81.

Wang, J., Feng, Z., Yao, D., Sui, J., Zhong, W., Li, M., \& Dai, J. (2008). Warfarin resistance in Rattus losea in Guangdong Province, China. Pesticide Biochemistry and Physiology , 91 (2), 90-95.

Watt, B., Proudfoot, A., Bradberry, S., \& Vale, J. (2005). Anticoagulant rodenticides. Toxicological reviews , 24 (4): 259-269.

Whisson, D., \& Salmon, T. (2002). Effect of the timing of applications and amount of $0.01 \%$ diphacinone consumed on mortality of California ground squirrels (Spermophilus beecheyi) Crop Protection 21 : 885-889

World Health Organization (1982). Instructions for determining the susceptibility or resistance of rodents to anticoagulants rodenticids. WHO Vector Biol. Control. Ser. 8: 843-849. 


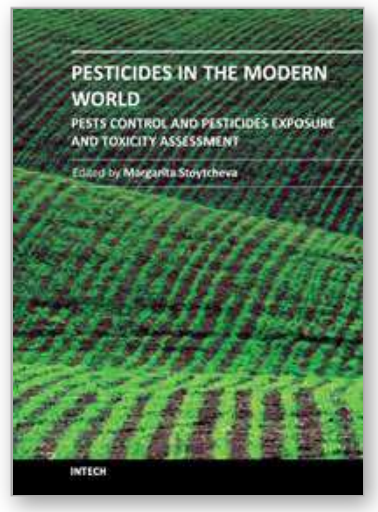

\section{Pesticides in the Modern World - Pests Control and Pesticides Exposure and Toxicity Assessment}

Edited by Dr. Margarita Stoytcheva

ISBN 978-953-307-457-3

Hard cover, 614 pages

Publisher InTech

Published online 30, September, 2011

Published in print edition September, 2011

The present book is a collection of selected original research articles and reviews providing adequate and upto-date information related to pesticides control, assessment, and toxicity. The first section covers a large spectrum of issues associated with the ecological, molecular, and biotechnological approaches to the understanding of the biological control, the mechanism of the biocontrol agents action, and the related effects. Second section provides recent information on biomarkers currently used to evaluate pesticide exposure, effects, and genetic susceptibility of a number of organisms. Some antioxidant enzymes and vitamins as biochemical markers for pesticide toxicity are examined. The inhibition of the cholinesterases as a specific biomarker for organophosphate and carbamate pesticides is commented, too. The third book section addresses to a variety of pesticides toxic effects and related issues including: the molecular mechanisms involved in pesticides-induced toxicity, fish histopathological, physiological, and DNA changes provoked by pesticides exposure, anticoagulant rodenticides mode of action, the potential of the cholinesterase inhibiting organophosphorus and carbamate pesticides, the effects of pesticides on bumblebee, spiders and scorpions, the metabolic fate of the pesticide-derived aromatic amines, etc.

\section{How to reference}

In order to correctly reference this scholarly work, feel free to copy and paste the following:

Philippe Berny (2011). Challenges of Anticoagulant Rodenticides: Resistance and Ecotoxicology, Pesticides in the Modern World - Pests Control and Pesticides Exposure and Toxicity Assessment, Dr. Margarita Stoytcheva (Ed.), ISBN: 978-953-307-457-3, InTech, Available from: http://www.intechopen.com/books/pesticides-in-themodern-world-pests-control-and-pesticides-exposure-and-toxicity-assessment/challenges-of-anticoagulantrodenticides-resistance-and-ecotoxicology

\section{INTECH}

open science | open minds

\author{
InTech Europe \\ University Campus STeP Ri \\ Slavka Krautzeka 83/A \\ 51000 Rijeka, Croatia \\ Phone: +385 (51) 770447 \\ Fax: +385 (51) 686166 \\ www.intechopen.com
}

\author{
InTech China \\ Unit 405, Office Block, Hotel Equatorial Shanghai \\ No.65, Yan An Road (West), Shanghai, 200040, China \\ 中国上海市延安西路65号上海国际贵都大饭店办公楼 405 单元 \\ Phone: +86-21-62489820 \\ Fax: +86-21-62489821
}


(C) 2011 The Author(s). Licensee IntechOpen. This chapter is distributed under the terms of the Creative Commons Attribution-NonCommercialShareAlike-3.0 License, which permits use, distribution and reproduction for non-commercial purposes, provided the original is properly cited and derivative works building on this content are distributed under the same license. 